\title{
The effect of copper on the uptake and translocation of spirotetramat insecticide on kiwifruit
}

\author{
D.B. Horgan and R.E. Gaskin \\ Plant Protection ChemistryNZ, P O Box 6282, Rotorua 3043, New Zealand \\ Corresponding author: david.horgan@ppcnz.co.nz
}

\begin{abstract}
Spirotetramat $\left(\right.$ Movento $\left.^{\circledR}\right)$ is a systemic insecticide that is used to control scale insects on kiwifruit. The use of protectant copper sprays on kiwifruit has become increasingly common due to the bacterial disease Pseudomonas syringae pv. actinidiae. This study investigated the interaction of copper with spirotetramat and how it influenced the uptake and translocation of spirotetramat within the plant. Movento ${ }^{\circledR}$ 100SC sprays should not be tankmixed with copper sprays because the uptake and translocation of spirotetramat is likely to be compromised. These negative effects were minimised when an organosilicone/organic fluid blend adjuvant $\left(\mathrm{Du}-\mathrm{Wett}^{\circledR}\right.$ ) was included in the tank mix. Pre-and post spray applications of copper, at least 1 week either side of spirotetramat applications, are unlikely to significantly affect the uptake and translocation of spirotetramat, and thus have any effect on its activity. There were no marked differences between two commercial copper formulations, in their effects on spirotetramat uptake but minor differences in translocation were observed.
\end{abstract}

Keywords copper sprays, kiwifruit, Actinidia chinensis.

\section{INTRODUCTION}

Spirotetramat (Movento ${ }^{\circledR}$, Bayer CropScience) is a systemic insecticide used to control scale insects (Hemiptera: Diaspididae) on kiwifruit (Actinidia chinensis and A. deliciosa) and protect new shoots emerging after foliar application. It distributes via the phloem and xylem in plants, to eliminate sucking insect pests (Brück et al. 2009).

Previously, Movento ${ }^{\circledR}$ 240SC with the addition of an esterified seed oil (2 litres/ha) was recommended by Bayer for use on kiwifruit (Bayer 2009). Earlier studies established that addition of an organosilicone superspreader adjuvant to this spray mix, and concentrating sprays by reducing application volumes, could increase uptake of spirotetramat into kiwifruit foliage (Gaskin et al. 2010) and improve its efficacy against scale (McKenna et al. 2013).
Since then, Bayer has replaced Movento ${ }^{\circledR} 240 \mathrm{SC}$ with Movento ${ }^{\circledR}$ 100SC for use on kiwifruit. The new product contains an alkylarylpolyglycol ether $(<25 \%$; Bayer CropScience 2012) in the formulation and the use of additional adjuvants is not recommended. It is not known what effect the addition of adjuvants will have on the performance of Movento ${ }^{\circledR}$ 100SC in controlling scale on kiwifruit.

The use of protectant copper sprays on kiwifruit has become an increasingly common practice due to the bacterial disease Psa (Pseudomonas syringae pv. actinidiae). They are potentially applied prior to, in tank mixes with, and post-spirotetramat applications. The effect of this on spirotetramat efficacy is unknown. This study investigated the interaction of copper with Movento ${ }^{\circledR} 100 \mathrm{SC}$ and 
how it may influence the uptake and translocation of spirotetramat within the plant.

\section{METHODS AND MATERIALS}

Gold3 kiwifruit (Actinidia chinensis Planch. cultivar 'Zesy002') potted plants were supplied by Plant \& Food Research, Te Puke, in November 2014. They had been grown under glasshouse/shadehouse conditions from tissue culture and were actively expanding pre-bloom. They were 1.5-2 $\mathrm{m}$ tall and all foliage was typical of spring growth. Plants were maintained outside at $\mathrm{PPC}_{\mathrm{NZ}}$, Rotorua, in ambient conditions (ranging from $3-25^{\circ} \mathrm{C}$, average $14.8^{\circ} \mathrm{C}$, $75 \% \mathrm{RH}$ ) under clear roofing to protect them from rain throughout the study, which commenced on 13 November 2014. Water was supplied regularly to pots without wetting foliage.

Prior to spirotetramat treatment, leaves (6) for six treatments were pre-sprayed with two commercial copper formulations (three treatments each). The chemicals used were cuprous oxide $\left(750 \mathrm{~g}\right.$ ai $/ \mathrm{kg}$, Nordox ${ }^{\mathrm{TM}} 75 \mathrm{WG}$, Gro-Chem) and copper hydroxide (300 g ai $/ \mathrm{kg}$, Kocide ${ }^{\circledR}$ Opti $^{\mathrm{TM}}$, Du Pont), to represent the two most commonly used protectant copper sprays on kiwifruit. The coppers were sprayed to run-off using a hand-sprayer, at commercial rates $(28 \mathrm{~g}$ ai/100 litres and $21 \mathrm{~g}$ ai/100 litres, respectively), on both leaf sides (adaxial and abaxial) at intervals of 3, 2 and 1 week before spirotetramat application.

The radiolabelled spirotetramat formulation $\left({ }^{14} \mathrm{C}\right.$-radiolabel specific activity $3.67 \mathrm{MBq} / \mathrm{mg}$, incorporated in Movento ${ }^{\circledR}$ 240SC formulation at 17.4 MBq/ml, 240 g/litre ai, Bayer CropScience) was modified as per confidential instructions (Han Eerens, Bayer CropScience, personal communication) to include an alkylarylpolyglycol ether oil, producing an equivalent formulation to Movento ${ }^{\circledR}$ 100SC. This spirotetramat formulation was used alone (96 $\mathrm{g}$ ai/ha) or in combination with an organosilicone/organic fluid blend adjuvant $\left(\right.$ Du-Wett ${ }^{\circledR}$, DW, Etec Crop Solutions; $40 \mathrm{ml} / 100$ litres). Some treatment mixes included the cuprous oxide or copper hydroxide formulations. Additional chemicals, fluopyram (500 g ai/litre, Luna ${ }^{\circledR}$ Privilege, Bayer CropScience) a systemic protectant fungicide and methoxyfenozide insecticide
(240 g ai/litre, Prodigy ${ }^{\mathrm{TM}}$, Dow AgroSciences), were also combined (at $15 \mathrm{ml}$ ai/100 litres and $9.6 \mathrm{~g}$ ai/100 litres, respectively) within two treatment mixes to mimic combined tank mixes that are often sprayed during the pre-bloom period. Spirotetramat treatments were applied to the leaves on 05 December 2014. Plants were assessed throughout the experiment to determine any treatment-induced phytotoxicity on leaf surfaces.

Treatments were applied by dispensing droplets $(25 \times 0.5 \mu \mathrm{l})$ with a repeating microsyringe to both the adaxial (upper) and abaxial (lower) leaf surfaces on the same leaf, on opposite sides of the midvein. The droplet density on leaves was applied to simulate the appropriate spray application volume (1000 litres/ha). Each treatment was replicated on six randomly selected, mature, fully expanded leaves from six separate plants. The quantity of radiolabelled spirotetramat applied to leaves in each treatment was determined by dispensing droplets (25) directly into scintillation vials (three replicates).

Uptake of spirotetramat in all treatments was determined at 7 days after treatment. Surface washes of the application sites, to recover unabsorbed insecticide, were made with $4 \times 4 \mathrm{ml}$ of acetone+water $(1+1 \mathrm{v} / \mathrm{v})$, then diluted with scintillant solution (ACS, Amersham Biosciences) and radioactivity was quantified using a liquid scintillation counter (Packard TriCarb 2100TR). Foliar uptake was defined as radiolabel not recovered by washes, calculated as a percentage of the applied amount.

After the surface wash-offs, treated leaves were harvested and sectioned at the midvein into upper and lower leaf surface application sites. They were stored separately for translocation analysis. Five treatments were left unharvested after treated leaves were washed in situ; four of these were sprayed with copper formulations (as per the pre-spray copper methods) at 1 and 2 weeks post-spirotetramat application and one treatment was left unsprayed. These treated leaves were subsequently harvested 19 days after spirotetramat application.

All the harvested treated leaves were stored frozen in separate sealed plastic bags until processed in a Biological Oxidiser (Harvey 
OX500). Radiolabelled spirotetramat within plant tissues was determined by combusting/ oxidising each leaf separately and absorbing the ${ }^{14} \mathrm{CO}_{2}$ generated in scintillant solution (Carbon-14 Cocktail, RJ Harvey), which was subsequently quantified by liquid scintillation counting. Combusting the treated leaves (after surface washing) determined the amount of spirotetramat remaining in the treated leaf at the harvest interval. The amount of translocation out of treated leaves was determined by difference; deducting the radioactivity recovered from washings plus the treated leaf from the known amount applied to each leaf.

Treatments were compared using analysis of variance (Statistix10) and least significant difference (LSD) tests. Variance stabilising transformations were made where necessary prior to analysis.

\section{RESULTS AND DISCUSSION Uptake}

Previous studies have confirmed that spirotetramat uptake into kiwifruit foliage is essentially complete within $24 \mathrm{~h}$ after application (Gaskin et al. 2010; R.E. Gaskin, unpublished data). Rain and dew on plant surfaces are also likely to limit uptake for prolonged periods, but once inside the plant, translocation of pesticides will proceed over time. Uptake was determined here at the single interval of 7 days after treatment.

Uptake of spirotetramat (as the Movento ${ }^{\circledR}$ 100SC formulation) into foliage (Table 1) was similar to that measured for Movento ${ }^{\circledR} 240 \mathrm{SC}+$ Partner ${ }^{\circledR}$ oil $(0.1 \%)$ in a previous study (Gaskin et al. 2010). The addition of DW adjuvant significantly $(\mathrm{P}=0.05)$ increased uptake into both adaxial and abaxial leaf surfaces. Combining copper, either cuprous oxide or copper hydroxide, with spirotetramat alone reduced spirotetramat uptake; by $28 \%$ and $40 \%$ respectively (Table 1 ). Both these treatments showed light phytotoxicity (spotting), on the abaxial leaf surface only, 1 week after treatment. The addition of DW adjuvant to the spirotetramat + copper treatments overcame the negative effects of copper and restored uptake levels close to that of spirotetramat + DW. The further addition of the typical tank-mixed pesticides, fluopyram and methoxyfenozide, had no effect on spirotetramat uptake.

These results suggest that uptake of spirotetramat sprays will generally benefit from the addition of DW adjuvant, and the adjuvant should be included whenever spirotetramat is tank-mixed with copper and other pesticide products.

Within individual treatments there were no differences in uptake between the adaxial

Table 1 Mean \% uptake at 7 days after treatment of radiolabelled spirotetramat ${ }^{1}$ from treatments with various insecticides, fungicides and copper formulations that had been applied to the upper and lower surfaces of kiwifruit leaves.

\begin{tabular}{lccc}
\hline Treatment & Adaxial & Abaxial & Mean \\
\hline Spirotetramat & $14.7 \mathrm{cde}^{2}$ & $18.5 \mathrm{bcd}$ & $16.6 \mathrm{BC}$ \\
Spirotetramat + DW & $23.0 \mathrm{ab}$ & $26.2 \mathrm{a}$ & $24.6 \mathrm{~A}$ \\
Spirotetramat + cuprous oxide & $11.2 \mathrm{de}$ & $12.7 \mathrm{de}$ & $12.0 \mathrm{CD}$ \\
Spirotetramat + DW + cuprous oxide & $18.8 \mathrm{abcd}$ & $20.3 \mathrm{abc}$ & $19.5 \mathrm{AB}$ \\
Spirotetramat + DW + cuprous oxide + & & & \\
fluopyram + methoxyfenozide & $14.7 \mathrm{cde}$ & $21.4 \mathrm{abc}$ & $18.0 \mathrm{~B}$ \\
Spirotetramat + copper hydroxide & $8.7 \mathrm{e}$ & $11.2 \mathrm{de}$ & $9.9 \mathrm{D}$ \\
Spirotetramat + DW + copper hydroxide & $16.6 \mathrm{bcd}$ & $20.9 \mathrm{abc}$ & $18.8 \mathrm{~B}$ \\
Spirotetramat + DW + copper hydroxide + & & & \\
fluopyram + methoxyfenozide & $16.0 \mathrm{bcde}$ & $21.3 \mathrm{abc}$ & $18.6 \mathrm{~B}$ \\
\hline
\end{tabular}

${ }^{1}$ Formulation approximating Movento ${ }^{\circledR}$ 100SC.

${ }^{2}$ Means sharing common lowercase or uppercase postscripts are not significantly different ( $\mathrm{P}=0.05$, LSD test). 
and abaxial leaf surfaces, although there was a consistent trend of slightly higher uptake from the lower leaf surface (Table 1). A similar result was reported on Hayward (spring) vines, although the trend was for slightly elevated uptake from the upper leaf surface in this variety (Gaskin et al. 2010).

The effect of pre-treating leaves with copper sprays before spirotetramat was applied generally had little effect on uptake of spirotetramat and there were no differences between copper formulations (Table 2). The leaf side treated had no significant effect on uptake $(\mathrm{P}=0.10)$. Leaves pre-sprayed with copper 3 weeks before spirotetramat application showed phytotoxic symptoms on both the upper and lower leaf surfaces, so much so that some leaf drop occurred in these treatments prior to spirotetramat application. The leaves pre-sprayed at 1 and 2 weeks before spirotetramat application did not show obvious phytotoxicity, but the 1-week presprayed leaves generally were in better health than the 2-week pre-sprayed leaves, indicating a level of physiological stress induced by the copper sprays.

\section{Translocation}

Translocation of spirotetramat in Gold3 foliage, was low $(\leq 3.1 \%)$ at 7 days after treatment (Table 3 ). This is in agreement with McKenna et al. (2013) who also confirmed that most of the translocation out of senescing Hort 16A leaves $(<3 \%)$ occurred within the first week.

Spirotetramat was translocated most in the treatment by itself, but not more than in spirotetramat + DW. Mixing cuprous oxide with spirotetramat significantly reduced translocation ( $\mathrm{P}=0.05)$, but addition of DW adjuvant rectified this. The further addition of fluopyram and methoxyfenozide had no effect on spirotetramat translocation (Table 3). The mixing of copper hydroxide with spirotetramat resulted in no movement of spirotetramat out of the treated leaf and the addition of DW adjuvant had no effect on this (Table 3 ).

Treatment was significant in these results $(\mathrm{P}=0.05)$ and suggests that tank-mixing spirotetramat with coppers may reduce systemic movement of spirotetramat, but that addition of DW adjuvant can alleviate this effect, depending on the copper formulation used.

Table 2 Mean \% uptake at 7 days after treatment of radiolabelled spirotetramat ${ }^{1}$ applied to the upper and lower surfaces of kiwifruit leaves that had been pre-treated with copper sprays 1, 2 or 3 weeks previously.

\begin{tabular}{|c|c|c|c|}
\hline Treatment & Adaxial & $\begin{array}{l}\text { \% Uptake } \\
\text { Abaxial }\end{array}$ & Mean \\
\hline Spirotetramat & 14.7 & 18.5 & $16.6 \mathrm{~B}^{2}$ \\
\hline Spirotetramat + DW & 23.0 & 26.2 & $24.6 \mathrm{~A}$ \\
\hline Spirotetramat + DW (cuprous oxide 1 week pre-spray) & 17.3 & 23.9 & $20.6 \mathrm{AB}$ \\
\hline Spirotetramat + DW (cuprous oxide 2 weeks pre-spray) & 14.8 & 22.5 & $18.7 \mathrm{AB}$ \\
\hline Spirotetramat + DW (cuprous oxide 3 weeks pre-spray) ${ }^{3}$ & 33.0 & 18.9 & $25.9-$ \\
\hline Spirotetramat + DW (copper hydroxide 1 week pre-spray) & 15.6 & 18.9 & $17.2 \mathrm{~B}$ \\
\hline Spirotetramat + DW (copper hydroxide 2 weeks pre-spray) & 24.5 & 23.2 & $23.9 \mathrm{AB}$ \\
\hline Spirotetramat + DW (copper hydroxide 3 weeks pre-spray) $)^{3}$ & 14.1 & 30.7 & $23.6-$ \\
\hline
\end{tabular}

${ }^{1}$ Formulation approximating Movento ${ }^{\circledR} 100 \mathrm{SC}$.

${ }^{2}$ Means sharing common postscripts are not significantly different ( $\mathrm{P}=0.05$, LSD test).

${ }^{3}$ Excluded from analysis due to multiple leaf loss (from phytotoxicity) before spirotetramat treatments were applied. 
Table 3 Mean translocation of radiolabelled spirotetramat ${ }^{1}$ (as \% of chemical applied) out of kiwifruit leaves at 7 days after treatment, when tank-mixed with and without other chemicals.

\begin{tabular}{lc}
\hline Treatment & Translocation \\
\hline Spirotetramat & $3.1 \mathrm{~A}^{2}$ \\
Spirotetramat + DW & $1.8 \mathrm{AB}$ \\
Spirotetramat + cuprous oxide & $0.3 \mathrm{~B}$ \\
Spirotetramat + DW + cuprous oxide & $1.4 \mathrm{AB}$ \\
Spirotetramat + DW + cuprous oxide + fluopyram + methoxyfenozide & $1.4 \mathrm{AB}$ \\
Spirotetramat + copper hydroxide & $0.0 \mathrm{~B}$ \\
Spirotetramat + DW + copper hydroxide & $0.0 \mathrm{~B}$ \\
Spirotetramat + DW + copper hydroxide + fluopyram + methoxyfenozide & $1.0 \mathrm{~B}$ \\
\hline
\end{tabular}

${ }^{1}$ Formulation approximating Movento ${ }^{\circledR} 100 \mathrm{SC}$.

${ }^{2}$ Means sharing common postscripts are not significantly different ( $\mathrm{P}=0.05$, LSD test).

Translocation values were low and replicate variation meant that treatment was not significant $(\mathrm{P}=0.34)$ in the pre- and post-copper spray study (Table 4). There was no strong trend for spirotetramat translocation to increase with time, with or without either copper spray.

In general, pre- and post-spraying with coppers, either cuprous oxide or copper hydroxide, had no negative effects on translocation of spirotetramat in
Gold3 kiwifruit plants. The phytotoxic symptoms resulting from copper sprays did not adversely affect translocation of the insecticide, suggesting that uptake and translocation of spirotetramat probably occurred quite rapidly in this foliage. The results suggest that pre and post-spraying of coppers within 1 week of spirotetramat application is unlikely to have any significant effects on the activity of spirotetramat in kiwifruit.

Table 4 Effect of pre- and post-application copper sprays on the mean translocation (as \% of chemical applied) of radiolabelled spirotetramat ${ }^{1}$ from treatments applied to kiwifruit leaves, at 7 and $19^{2}$ days after treatment.

\begin{tabular}{lcc}
\hline Treatment & $\begin{array}{c}\text { Days after } \\
\text { treatment }\end{array}$ & Translocation \\
\hline Spirotetramat & 7 & $3.1 \mathrm{BC}^{3}$ \\
Spirotetramat + DW & 7 & $1.8 \mathrm{BC}$ \\
Spirotetramat + DW & 19 & $6.0 \mathrm{ABC}$ \\
\hline Spirotetramat + DW (cuprous oxide 1 week pre-spray) & 7 & $4.1 \mathrm{ABC}$ \\
Spirotetramat + DW (cuprous oxide 2 weeks pre-spray) & 7 & $1.6 \mathrm{C}$ \\
Spirotetramat + DW (cuprous oxide 3 weeks pre-spray) & 7 & $9.0 \mathrm{AB}$ \\
Spirotetramat + DW (cuprous oxide 1 week post-spray) & 19 & $6.1 \mathrm{ABC}$ \\
Spirotetramat + DW (cuprous oxide 2 weeks post-spray) & 19 & $5.2 \mathrm{ABC}$ \\
\hline Spirotetramat + DW (copper hydroxide 1 week pre-spray) & 7 & $3.5 \mathrm{BC}$ \\
Spirotetramat + DW (copper hydroxide 2 weeks pre-spray) & 7 & $2.2 \mathrm{BC}$ \\
Spirotetramat + DW (copper hydroxide 3 weeks pre-spray) & 7 & $4.0 \mathrm{ABC}$ \\
Spirotetramat + DW (copper hydroxide 1 week post-spray) & 19 & $11.2 \mathrm{~A}$ \\
Spirotetramat + DW (copper hydroxide 2 weeks post-spray) & 19 & $6.6 \mathrm{ABC}$ \\
\hline
\end{tabular}

${ }^{1}$ Formulation approximating Movento ${ }^{\circledR} 100 \mathrm{SC}$.

${ }^{2}$ Leaves harvested later due to timing of post-treatment copper sprays, but all treatments were washed from leaf surfaces (to determine uptake) at 7 days after treatment.

${ }^{3}$ Means sharing common postscripts are not significantly different ( $\mathrm{P}=0.05$, LSD test). 


\section{CONCLUSIONS}

Spriotetramat sprays should not be tank-mixed with copper sprays because the uptake and translocation of spirotetramat is likely to be compromised. These negative effects may be minimised if DW adjuvant is included in the tank mix. Pre-and post spray applications of copper, at least 1 week either side of spirotetramat applications, are unlikely to significantly affect the uptake and translocation of spirotetramat, and thus have any effect on its activity. There were no marked differences between cuprous oxide and copper hydroxide in their effects on spirotetramat uptake although minor differences in translocation were observed.

\section{ACKNOWLEDGEMENTS}

Bayer CropSciences provided the radiolabelled insecticide. Justin Nairn and Rebecca van Leeuwen provided technical assistance. Cathy McKenna supplied potted kiwifruit plants. Funding was provided by ZESPRI / KVH and the MPI Sustainable Farming Fund.

\section{REFERENCES}

Bayer CropScience 2009. Movento Insecticide. https://www.bayercropscience.us/products/ insecticides/movento (accessed 15 November 2014).

Bayer CropScience 2012. Safety Data Sheet Movento ${ }^{\circ}$ 100SC. Issued 13 September 2012. 6 pp.

Brück E, Elbert A, Fischer R, Krueger S, Kühnhold J, Klueken AM, Nauen R, Niebes J-F, Reckmann U, Schnorbach H-J, Steffens $\mathrm{R}$, van Waetermeulen X 2009. Movento', an innovative ambimobile insecticide for sucking insect pest control in agriculture: Biological profile and field performance. Crop Protection 28: 838-844.

Gaskin RE, Horgan DB, van Leeuwen RM, Manktelow DW 2010. Adjuvant effects on the retention and uptake of spirotetramat insecticide sprays on kiwifruit. New Zealand Plant Protection 63: 60-65.

McKenna C, Gaskin R, Horgan D, Dobson S, Jia Y 2013. Efficacy of a postharvest spirotetramat spray against armoured scale insects on kiwifruit vines. New Zealand Journal of Crop and Horticultural Science 41: 105-116. 